\title{
Obraz wojen krzyżowych i krzyżowców w prozie Zofii Kossak, Jana Dobraczyńskiego i Jarosława Iwaszkiewicza
}

Dariusz Wybranowski 
UAPIS Seria VII 2001

\section{Dariusz Wybranowski}

\section{Obraz wojen krzyżowych i krzyżowców w prozie Zofii Kossak, Jana Dobraczyńskiego i Jarosława Iwaszkiewicza}

$\mathrm{P}$ roblemem wiodącym niniejszego artykułu będzie konfrontacja obrazu postaci krzyżowców, wypraw krzyżowych i epizodów z dziejów państw łacińskich na Bliskim Wschodzie, przekazanego przez wymienionych w tytule autorów, ze źródłami, a także autentyczność zdarzeń i postaci zaprezentowanych przez literaturę piękną wobec stanu badań nad dziejami krucjat słowem: kwestia, na ile obraz literacki ma cechy wspólne z rzeczywistością średniowiecza i czasów wypraw krzyżowych.

Przedmiot badań to postać krzyżowca, jego sylwetka i obraz psychologiczny oraz przebieg i reperkusje konfrontacji Łacinników z muzułmanami, zarówno militarnej, jak i cywilizacyjnej. Jeszcze jeden aspekt badawczy to refleksje krzyżowców wynikające $z$ ich zetknięcia się ze światem tak krańcowo odmiennym od tego, który wcześniej znali, i pytanie, na ile wpłynęło to na ich sposób widzenia rzeczywistości. Podstawowym materiałem badawczym dla autora są powieści: Krzyżowcy, Król trędowaty i Bez oręża Zofii Kossak, Czenwone tarcze Jarosława Iwaszkiewicza oraz Klucz mądrósi Jana Dobraczyńskiego ${ }^{1}$.

Twórczość wspomnianych trzech autorów ukazuje panoramę epoki wypraw krzyżowych od schyłku XI wieku po rok 1260 i czasy poprzedzające ostateczny upadek Królestwa Jerozolimskiego.

Dla lepszego ukazania badanych kwestii całość została podzielona następująco: każdorazowo po ukazaniu typowych cech charakteru rycerstwa (w tym waleczności, wiary i pobożności, bez-

\footnotetext{
1 Cyt. wydania: Z. Kossak, Krzyżowcy, t. 1: Bóg tak chce; t. 2: Fides Graeca; t. 3: Wieża trzech sióstr; t. 4: Jerozolima wyzwolona, Bielsko-Biała 1989 (dalej: $K r \mathrm{z}$ numcracją tomu i paginacją w nawiasach); eadem, Król trędowaty, Warszawa 1971 (dalej: KT); eadem, Bez oręża, t. 1-2 [w 1 wol.], Warszawa 1983 (dalej: BO); J. Iwaszkiewicz, Czerwone tarcze, Warszawa 1970 (dalej: CT); J. Dobraczyński, Klucz mądrości, Warszawa 1975 (dalej: KM).
} 
względności, prawości, stosunku do kobiet) i jego mentalności autor zestawił literacki obraz zmagań wojen krzyżowych z obrazem źródłowym i stanem badań.

\section{Waleczność i odwaga}

Te cechy osobowości rycerstwa są niejednokrotnie eksponowane na kartach pierwszej części tryptyku Zofii Kossak. Odwaga, waleczność i umicjętność posługiwania się orężem to bardzo istotny miernik wartości rycerza. Typowym przykładem odwagi połączonej z prymitywizmem i brutalnościąjest rycerz de Melun, który powiedział zuchwale cesarzowi Aleksemu I, że w swoim hrabstwie na słupie powiesił wiadomość o tym, iż każdy może się z nim bić, ale jakoś nigdy nikt się nie odważył ( $K r$ I 171-172). Rycerz de Melun to człowiek znany ze swej siły, odważny do szaleństwa, ale zupełnie słaby i bezbronny w obliczu głodu i pragnienia, zdolny wtedy do największej nikczemności ( $K r$ III 54-55, 158). Jego czyn w postaci przejścia na islam za cenę jedzenia okrył hańbą całą krucjatę (Kr IV 187-188).

O odwadze i sprawności rycerzy zachodnich w walce Anna Komnena, córka cesarza Aleksego I, pisała:

Sułtan miał przed oczyma bezkresne tłumy Latynów, poznał też ich wielką brawurę na polu bitwy ${ }^{2}$.

I wyznawcom islamu, i Łacinnikom imponuje waleczność i pogarda śmierci przeciwnika ( $K r$ II 222, IV 182). Emir Usama ibn Munkidh z Szajzaru na kartach swej księgi niejednokrotnie zaświadcza o kontaktach z krzyżowcami, także podczas walki. Dostrzega wprawdzie odwagę Łacinników, lecz pisze wprost:

Każdy człowiek, który dobrze poznał Franków, będzie tylko wysławiał Allaha Najwyższego i święcił jego imię. Bo zobaczył on w nich tylko zwierzęta, obdarzone cnotą odwagi w walce i niczym więcej; podobnie jak zwierzęta odznaczają się cnotą w walce ${ }^{3}$.

Dowodem waleczności rycerstwa mają być worki głów tureckich ukazane Grekom, dla których to jeszcze jedna oznaka dzikości i barbarzyństwa Eacinników ${ }^{4}$. Dla krzyżowców koronnym przykładem fidei Graecae jest sprawa przejęcia Nicei przez Bizantyjczyków na drodze tajnych układów z Turkami (GF 39; Kr II 300). W opinii Greków rycerstwo łacińskie to zagadka, niektórzy widzą w nim postacie jak z eposów Homera, z drugiej jednak strony dostrzegają prostactwo, nieokrzesanie, brak higieny, brud, zasklepienie umysłowe i pogardę dla wiedzy ( $K r$ II 172-173, 220). Nawet

\footnotetext{
2 Anna Komnena, Aleksjadı, tł. i opr. O. Jurewicz, t. 2, Wrocław 1972 (Bibliotcka Przckładów z Litcratury Antyczncj 19), s. 105 (ks. XI, rozdz. 5).

3 Usama ibn Munkidh, Kitab al-I'tibar. Ksiega pouczających przykladów, tł. J. Bielawski, Wrocław 1975, s. 232.

${ }^{4}$ Zob. Anna Komnena, Aleksjada, op. cit.; Anonima dzieje pierwszej krucjaty albo czyny Franków i pielgrzymów jerozolimskich, tł. i opr. K. Estreicher, Warszawa-Kraków 1984, s. 37 (tyt. oryg.: Gesta Francorum et aliorum Hierosolymitanorum — dalcj: GF z paginacją w nawiasach); Kr II 264.
} 
Anna Komnena u Kossak nie szczędzi Łacinnikom gorzkich ocen, jest jednak pod wrażeniem ich męstwa uosobionego w postaci Boemunda z Tarentu ( $K r$ II 221). Zdumienie u Greków budzi nie tylko odwaga i waleczność rycerzy, lecz także wierność przysiędze rycerskiej i danemu słowu (Kr II 168).

Brak odwagi i słabość jest u rycerstwa bezlitośnie piętnowana. Stefan z Blois, który opuścił krucjatę, został w kraju okrzyknięty tchórzem, nawet żona i syn odwrócili się od niego ${ }^{5}$. Życie stało się dla Stefana tak dalece nieznośne, że zdecydował się powrócić na Wschód i dołączyć do krzyżowców w ich drodze do Jerozolimy.

Podczas zmagań z muzułmanami waleczność i odwaga jest przedmiotem rywalizacji pomiędzy oddziałami rycerstwa z różnych krajów. To zjawisko uchwyciła doskonale Kossak, pisząc:

Rycerze śląscy przygnali tutaj z pierwszym oddzialem Rajmunda St. Gilles i czynią śmiele z plugawcami [Turkami Seldżuckimi - D. W.] na podziw innym narodom. W takich chwilach, gdy obcy patrzą z uznaniem na ich męstwo, sprawność, znajomość wojennego rzemiosła, Ślązacy czują nie znaną przedtem dumę z przynależności do swego plemienia, krzepką radość, że są nie tylko równi, ale lepsi od zachodnich mądralów, a zarazem ten sam wieczny, gorzki żal, że przyszli tutaj garsteczką bez wodza, bez króla... Hej! Pokazaliby światu, co Polacy znaczą! Dziwiliby się Frankowie ich czynom... (Kr III 26).

W powieści występuje też barwna postać polskiego rycerza Ostoja z rodu Jastrzębców, najpierw jeńca i niewolnika, a potem krzyżowca, który wiele dobrego się nauczył od muzułmanów. Jego wiedza i rozwaga pozwoliła nieraz na udzielanie rycerzom zachodnim rozsądnych rad (Kr III 157 i n.). Nie ma wprawdzie żadnych wiarygodnych przekazów o udziale rycerzy z ziem polskich w I krucjacie, ten wątek jest jedynie doskonałym ubarwieniem powieści. Wspólna walka służyła stopniowemu tworzeniu się poczucia świadomości narodowej, problem opisany u rycerzy śląskich mógł być autentyczny i u prawdziwych krzyżowców - Normanów, Prowansalczyków, Lotaryńczyków, mieszkańców Flandrii i innych krajów.

Odwaga zgodna z etosem rycerskim i polączona z prawością charakteru to sylwetka Tankreda, siostrzeńca księcia Normanów Boemunda z Tàrentu. Na kartach Krzyżowców Tankred miał ocalić po zdobyciu Nicei żonę sułtana lkonium, która została pojmana przez krzyżowców wraz z dzieckiem (Kr II 290-291). Szlachetność Tankreda, jak wspominają Gesta Franconum, pozwoliła ocalić też część mieszkańców Jerozolimy od rzezi po zdobyciu miasta (GF 122).

Todobną postacią był zaprezentowany przez Kossak w Bez oręża rycerz Jan de Brienne, późniejszy król jerozolimski. Jan był nie tylko waleczny, co pokazało oblężenie Damietty w delcie Nilu, ale i rozważny, co u innych rycerzy nie było cechą pierwszoplanową (BO II 167-168).

Najlepiej problem nadmiernej wojowniczości rycerstwa, zwlaszcza przybyłego świeżo z Europy, ujął Rajmund III z Trypolisu. Powiedział z goryczą, że Królestwo Jerozolimskie zginie nie przez brak waleczności, lecz raczej przez jej nadmiar, gdy chce się atakować każdego, kto nosi turban, nawet tych,

${ }^{5}$ Kr IV 282; zob. też: R. Pernoud, Kobieta w' czasach wypraw krzyżow'ych, tł. I. Badowska, Gdańsk 1995, s. 29. 
którzy jak emir Damaszku chcieliby przymierza z Łacinnikami (KT 59). Hrabia Rajmund znany był ze swej odwagi rycerskiej, ale dla wielu rycerzy jerozolimskich pozostał podejrzany z racji swej rozwagi w postrzeganiu muzułmanów.

Zofia Kossak wzorem męstwa chrześcijańskiego uczyniła również króla Baldwina IV Trędowatego, człowieka śmiertelnie chorego, który jednak uczynił rzecz na pozór niemożliwą. W roku 1177 pokonał samego Saladyna w bitwie pod Montgisard, która była jednym z największym triumfów militarnych Królestwa Jerozolimskiego w czasach krucjat (KT 132 i n.). Współczesny historyk krucjat zaliczył zwycięstwo króla Baldwina do bardzo znaczących, słusznie jednak zauważył, że wprawdzie chwilowo uratowało Królestwo od zguby, na dłuższą metę jednak nie zmieniło jego sytuacji ${ }^{6}$.

Siła woli, rozsądek, wola utrzymania pokoju z sułtanem, talent dowódczy i myślenie kategoriami państwa mogłyby uczynić Baldwina najwybitniejszym z władców jerozolimskich, gdyby nie zniweczył tego postępujący trąd. Nie baronowie, którzy lekkomyślnie wyruszyli na zdobycie Aleppo i wrócili z niczym, ale właśnie ten człowiek - zdaniem Kossak - mógł uratować Królestwo (KT 39-40, 105-106, 138).

Ślepa odwaga i awanturnictwo, nie poparte jednak jakimkolwiek wyczuciem sytuacji politycznej, oraz chciwość to cechy Renalda de Chatillon, pana na zamku Krak de Moab. To właśnie jego niczym niesprowokowany napad na karawanę zdążającą do Mekki spowodował wojnę, która zakończyła się klęską pod Hittin i zdobyciem Jerozolimy przez Saladyna w 1187 r. ${ }^{7}$ Zarówno pan de Chatillon, jak i jego napad to wątki autentyczne. Renald figuruje w opisach Wilhelma z Tyru, a jego napady $z$ lat 1180-1182 na muzułmańskie wybrzeża Morza Czerwonego zostały odnotowane przez kronikarzy arabskich ${ }^{8}$.

Dla Zofii Kossak rycerz de Chatillon to symbol bohatera negatywnego, człowieka, który nigdy niczego się nie nauczy ani nic nie zrozumie. Jedyny sens jego życia to grabież i walka z muzułmanami. Wrogość i niechęć do nich pogłębił kilkunastoletni pobyt w niewoli (KT 61). Dialog pomiędzy de Chatillonem a Rajmundem III z Trypolisu ukazał przepaść pomiędzy obydwoma rycerzami w ocenie ówczesnej sytuacji politycznej Królestwa i wyznawców islamu. Rajmund $\mathrm{z}$ naciskiem wskazał również na fakt mocnych stron położenia geograficznego państewek łacińskich i rozsądnej pomocy z Zachodu, to znaczy takiej, która uderza we wrogów, a nie w sojuszników (KT 61).

O ile dla hrabiego Trypolisu pobyt u muzułmanów w niewoli stał się okazją do zrozumienia kultury islamu i przyjaźni z niektórymi emirami, o tyle rycerz de Chatillon nie szczędzi im słów nienawiści:

\footnotetext{
${ }^{6}$ Zob. S. Runciman, Dzieje wypraw krzyżouych, t. 2: Królestwo Jerozolimskie ifrankijski Wschód 1100-1187, th. J. Schwakopf, Warszawa 1987, s. 381.

7 Zob. ibidem, s. 396-397.

${ }^{8}$ Zob. ibidem, s. 481, przyp. 1-2; P. M. Holt, Bliski Wschód od wypraw krzyżouvch do 1517 roku, th. B. Czarska, Warszawa 1993, s. 72; R. Pernoud, op. cit., s. 113.
} 
Durne pogany, śmierdzące kozłem i piżmem! Ani im się równać do nas! Co i nie dziwota, skąd mają mieć oświecenie, które tylko od Ducha Świętego pochodzi! (KT61)

Zresztą ten sposób myślenia podziela część rycerstwa i duchowieństwa łacińskiego, bo przecież rycerz nie paktuje z niewiernymi, ale ich zwalcza. Te słowa autorka włożyła w usta między innymi księcia Filipa flandryjskiego, przebywającego $w$ latach osiemdziesiątych $z$ pielgrzymką w Jerozolimie ${ }^{9}$.

Podobny typ rycerza i sposób myślenia ukazał Jan Dobraczyński w osobie hrabiego Juliana z Sydonu. Julian napadł na podjazd mongolski, którym dowodził Senang, syn nojona Kitbuki, dowódcy korpusu pozostawionego przez chana Hulagu w Syrii (KM 196 i n.). Podczas walki Senang zginął. Ceną za to było zniszczenie przez Mongołów Sydonu i bardzo bliska perspektywa wojny z Łacinnikami, która mogła obrócić całe Królestwo w ruinę. W powieści hrabia Julian, próbując usprawiedliwić swe niegodne postępowanie, mówi:

My, rycerze chrześcijańscy, obrońcy Grobu Świętego walczymy z poganami zawsze, gdziekolwiek ich spotkamy (...). Rycerze z Europy nawykli są do walki, a nie do gadania z Tartarami (KM 197).

Brak jakiejkolwiek rozwagi, chciwość, buta i zaślepienie Juliana z Sydonu naraziły na szwank całą misternie prowadzoną koncepcję sojuszu z Mongołami, co mogło wplątać Łacinników w beznadziejny konflikt z najpotężniejszym wówczas imperium na Ziemi. Tylko mądrość i rozwaga króla Małej Armenii, Hettuma oraz szczerość wiary i szlachetność Kitbuki zapobiegła zdobyciu miasta Nazaret i przyszłej zagładzie Królestwa Jerozolimskiego (KM 227-229).

Inne przykłady dążenia rycerstwa jerozolimskiego do wojny za wszelką cenę to polityka i osoby wielkich mistrzów zakonu templariuszy: Odo de St. Amanda i Gerarda de Ridefort. O ile jednak w przypadku Renalda de Chatillona była to chciwość połączona z głupotą i brakiem wyobraźni, o tyle w przypadku rycerzy Templum działały polityczne ambicje i wyrachowanie (KT 63-64). Szczególnie złowroga postać to wielki mistrz Odo, jego następca nie okazal się od niego lepszy $(K T$ 138, 160). Jak wskazała badaczka dziejów zakonu, Gerard de Ridefort

...posiadał w nadmiarze wady Odona de St. Amand., bez wyrównujących je zdolności wojskowych oraz niezłomnego charakteru. Gerard nie posiadał zadnych militarnych zdolności; przeciwnie, dowiódł nader upartej woli przeżycia wszystkich klęsk, jakie spowodowat ${ }^{10}$.

Nieco mniej surowo ocenia go Malcolm Barber, który wskazuje na pewną tendencyjność opisu osoby wielkiego mistrza de Rideforta, spowodowaną między innymi związkiem kronikarza Ernoula z wrogim w stosunku do zakonu rodem Ibelinów, przyznaje jednak, że interpretację kronikarza przyjmuje dziś większość historyków ${ }^{11}$. Zofia Kossak patrzy na templariuszy w bardzo podobny

9 KT 59: „Jawnie powiadacie, książę, że należy popierać niewiernych?! Poganów!? Zali podobna rzecz przystoi chrześcijaninowi? Zali jedynym obowiązkicm rycerza nie jest walka z nimi?...".

${ }^{10}$ M. Melville, Dzieje templariuszy, tt. A. Jędrychowska, Warszawa 1991, s. 107, 113.

11 Zob. M. Barber, Templariusze, tł. R. Sudół, Warszawa 1999, s. 101. 
sposób jak kronikarz Wilhelm z Tyru, który uważał zakon za symbol wszelkiego zła ${ }^{12}$. W powieści kilku templariuszy należy do tajemniczej sekty, której członkowie są wyznawcami kultów pogańskich i gorliwie korzystają z wdzięków porwanych niewolnic (KT 156 i n.). Obraz braci zakonnych u Kossak żywo przypomina materiał z procesu przeciwko templariuszom z lat 1307-1312, gdy oskarżano ich o oddawanie czci bożkom i plucie na Krzyz ${ }^{13}$. Podczas przesłuchań templariusze przyznawali się pod wpływem tortur do wszystkich stawianych im zarzutów. Jednak, jak ukazują źródła i badania, braciom zakonnym: zarówno templariuszom, jak i joannitom, nie sposób odmówić waleczności, talentów wojskowych i determinacji w boju, czego dowodem była ich postawa podczas wszystkich bitew stoczonych z muzułmanami ${ }^{14}$.

Cechy negatywne łączące de Chatillona i templariuszy zbiegly się również w osobie innego z bohaterów Zofii Kossak, znanego z V krucjaty legata papieskiego Pelagiusza. To jego zaślepienie i ambicje pogrzebały bardzo korzystne propozycje sułtana Egiptu i pchnęły krzyżowców do beznadziejnego marszu na Kair zakończonego klęską (BO II 267 i n.). Kossak nakreśliła obraz kardynała Pelagiusza jako człowieka skrajnie dumnego, ambitnego, zadufanego w sobie, posiadającego monopol na rację:

...zadawniona niechęć do rycerstwa, do wielmożów, jak ich pogardliwie nazywał, była w jego duszy zbyt mocna, by ją rozsądek zdołał przełamać. Wierzył silnie w to, że postępuje dobrze, gdy postępuje przeciwnie, niż radzą baroni. Wierzył też, że da sobie radę bez pomocy Jana de Brienne. Bóg go wspomoże, Bóg go natchnie właściwym postanowieniem, pokieruje wszystkim, jak kierował dotąd. W przekonaniu kardynała tak się szczęśliwie składało, że Bóg chciał zawsze tego samego, co on (BO II 268).

Negatywny obraz polityki Pelagiusza utrzymał się w równiez w historiografii ${ }^{15}$.

\section{Pobożność}

Ta cecha została także bardzo wyraźnie nakreślona przez Zofię Kossak, Jarosława Iwaszkiewicza i Jana Dobraczyńskiego. Wspaniały fragment dotyczący opisu krzyża jako źródła wszechrzeczy jest u Kossak podstawą wiary biskupa Ademara de Monteil, dowódcy pierwszej krucjaty, pozwala mu na przetrwanie najtrudniejszych chwil i kłótni między przywódcami oddziałów łacińskich (Kr III 8-9). Ademar to typ krzyżowca, który obok wiary znajduje jednak zrozumienie dla słabości ludzkiej i potrafi wybaczyć w imię miłości chrześcijańskiej. Dowodem tego jest jego prośba o wyrozumiałość dla kobiet, które pod wpływem strachu i obawy o życie były skłonne oddać się muzułmanom ( $K r$ III 34-36). Jest

${ }_{12}$ Zob. M. Melville, op. cit., s. 66 i n.

${ }_{13}$ Zob. ibidem, s. 280 i n.

${ }^{14}$ Zob. E. Potkowski, Zakony rycerskie, Warszawa 1995, s. 112.

${ }^{15}$ Zob. S. Runciman, op. cit., t. 3, s. 160 i n.; H. E. Maycr, Geschichte der Krelizziige, Stuttgart-Berlin-Köln 1989,

s. 197 i n.; W. i M. Hrochowie, Krzyżowcy w Lewancie. Wobronie grobu Chrystusa, th. Z. Dobrzyniccki, Warszawa 1992,

s. $216-217$. 
przeciwstawieniem pełnego fanatyzmu i hipokryzji Arnulfa de Rohes, późniejszego patriarchy jerozolimskiego ( $K r$ III 35).

Anna Komnena, opisując moment nadejścia krucjaty, wskazała dobitnie na motywy kierujące jej uczestnikami. Jej zdaniem

...maluczcy szczerze chcieli złożyć hold Grobowi Świętemu i zwiedzić miejsca święte $(\ldots)^{16}$.

Głęboka religijność nie przeszkadza jednak chwilom zwątpienia u krzyżowców, ale odpowiedzią na chwilowe słabości i niedostatek jest głębokie przekonanie, ze „Bóg tak chce” i „Bóg pomoże zwyciężyć” (Kr II 255). Baldwin IV — „Król Trędowaty” — pragnie uzdrowienia ze swej choroby. Zadaje dramatyczne pytania wzorem biblijnego Hioba, modląc się o odpowiedź u Grobu Pańskiego (KT 76 i n.).

Głód, pragnienie i śmierć tysięcy ludzi, jakie spadają na krzyżowców podczas marszu przez Anatolię i podczas pobytu w Antiochii, skłaniają do pytania, czy aby cała krucjata to nie dzieło Szatana ( $K r$ II 185 i n.).

O to samo będzie pytał Boga Piotr Eremita ( $K r$ II 186, 214-215, 267). U Zofii Kossak Piotr to postać głęboko tragiczna. Charyzmatyczny przywódca „krucjaty ludowej”, wielbiony jak święty, to także przykład machiavellowskiego „nieuzbrojonego proroka”. Gdy nadszedł głód, ci, którzy go wcześniej chwalili, obrócili się przeciwko niemu. Z wodza stał się pośmiewiskiem i obiektem pogardy (Kr I 125). Zofia Kossak uczyniła go jednak przez chwilę bohaterem, gdy jako poseł do emira Kerbogi potrafił odmówić jedzenia, będąc głodny od wielu dni w Antiochii ( $K r$ III 183 i n.). Słabość i kruchość ciała Piotra oraz jego siła woli została przeciwstawiona niemal nadludzkiej sile fizycznej rycerza de Melun, który w momencie próby okazał się człowiekiem słabym.

Zapał do walki z „niewiernymi” znalazł ujście w pogromach Żydów w Nadrenii, dokonanych przez krzyżowców dowodzonych przez rycerzy Gottschalka i von Emicha, postacie autentyczne, biorące udział w „krucjacie ludowej” Piotra Eremity ${ }^{17}$. Bandom niekarnego tłumu, żądnym krwi i bogactwa odebranego pomordowanym, Zofia Kossak przeciwstawia tych szlachetnych i uczciwych rycerzy niemieckich, którzy chcieli surowo ukarać uczestników pogromów (Kr I 124).

Dla Zofii Kossak symbolem krzyżowca jest postać Godfryda de Bouillon. Godfryd to wcielenie prawości rycerskiej i żarliwej wiary. Tylko jego interwencja uchroniła jeden z bogatych kościołów w Konstantynopolu od profanacji i grabieży przezjego brata Baldwina i innych rycerzy (Kr II 176-177). Podobnie jak biskup Ademar, Godfryd pragnie dojść do Jerozolimy, by spełnić śluby, chce jednak potem szukać spokoju w klasztorze na Synaju ( $K r$ IV 313). Korona jerozolimska była dla niego nie spełnieniem ambicji, lecz ciężarem, który musiał nieść wbrew swej woli ( $K r$ IV 317).

Pobożność krzyżowców ma niekiedy wymiar głęboko mistyczny. Stara, zardzewiała włócznia znaleziona pod Antiochią była czynnikiem, który natchnął Łacinników wiarą w zwycięstwo ${ }^{18}$.

\footnotetext{
${ }^{16}$ Anna Komnena, op. cit., s. 84 (ks. X, rozdz. 10).

17 Zob. S. Runciman, op. cit., t. 1, s. 130 in.

18 O cudownym znalezicniu włóczni w ślad za wizją pielgrzyma Piotra wspomina Anonim (zob. GF 88-89, 94).
} 
Próba ognia, którą zwycięsko przeszedł kleryk Bartłomiej, okazuje się szokiem dla chłodnych i cynicznych ludzi w rodzaju Boemunda i Arnulfa de Rohes, którzy na kartach książki całą sprawę świętej włóczni z góry ukartowali (Kr IV 220 i n.). Oddział rycerstwa, który przybył w krytycznym momencie pod Doryleum i podczas oblężenia Jerozolimy, niedługo potem zyskał wymiar armii duchów zesłanej przez Boga, która pokonała muzułmanów (GF 43; Kr III 23; IV 295; KT 117-118). Po wielu latach o tej historii opowiadał w Królu trędowatym stuletni uczestnik I krucjaty, Robert de Corbier (KT 117).

To wiara pozwoliła także przejść Pustynię Syryjską, podobnie jak biblijnym Izraelitom, a biskup Ademar de Monteil stał się odpowiednikiem Mojżesza ( $K r$ III 49).

Żarliwość wiary nie przeszkadza jej powierzchowności, Łacinnicy wierzą głęboko w sądy boże (ordalia), co jest dla Greków dowodem ich barbarzyństwa (Kr II 172). U Zofii Kossak panicznie boją się nie tylko diabła, demonów, czarów, czarowników i magii, ale i tego, co widzą, na przykład bogactwo Greków i ich wiedzę traktują jak czary (Kr I 141-143, II 147-148, 154, 233, 251, 265 i n.).

Problemy moralne trapiące krzyżowców u Zofii Kossak mają wymiar głębszy, czasy krucjat to tylko kostium historyczny dla chrześcijan i ludzi wierzących w każdej epoce.

Schematy wiary wydatnie wpływają na mentalność i sposób postrzegania świata przez krzyżowców. Mimo iż Bizantyjczycy i inni chrześcijanie wschodni mieli być sprzymierzeńcami, rycerstwo krzyżowe darzy ich głęboką niechęcią i wrogością jako schizmatyków ( $K r$ II 155, 258; BO II 218, 273). Bardziej jednoznaczni są wyznawcy islamu. Już anonimowy autor Gesta Francorum, widząc męstwo muzułmanów, uważał, że istnieją tylko dwa prawdziwie rycerskie narody na świecie: Turcy i Frankowie (GF 44). „Pogany plugawe ... ale w boju dobrze stają... Rycerze są” mawiaja krzyżowcy, ponadto

...waleczni, lecz równocześnie, zdaniem Latynów, obrzydliwie chytrzy, nieuczciwi, nie trzymający się przepisów szlachetnej walki (...) krzyżowcy przekonali się, że muszą wbrew wszelkim zwyczajom walczyć po zachodzie słońca. Noca, jak zbóje! (Kr II 233, III 60).

Muzułmanie to wprawdzie wróg, ale wróg jednoznacznie określony.

Dla niektórych szczerze wierzących muzułmanów chrześcijanie i ich religia to zagadka. Emir al Bara, potomek chrześcijańskiej branki, chce przezwyciężyć wrogość do Łacinników, poznać lepiej dowódcę zamku Krak de Moab i porozmawiać z nim na temat religii (KT 124). Nie wie jednak, że rządzi tam od niedawna Renald de Chatillon...

Dylemat braku jednoznacznej oceny krzyżowców Zofia Kossak i Jan Dobraczyński włożyli w usta kilku muzułmanów, między innymi sułtana Saladyna i atabeka Bajbarsa (KT 135; KM 347). Frankowie to $\mathrm{z}$ jednej strony

...plemię podłe, zdradzieckie i okrutne, z drugiej zaś zdolne do nadludzkiego męstwa i odwagi, 
Bajbars nienawidzi Łacinników, widząc w nich ludzi interesownych i skłonnych do zdrady i podłości, ceni jednak „schizmatyka” - króla Hettuma $(K T$ 135, 137). Także rozmowa hrabiego Renalda z Sydonu i emira Naima al Bary to swoisty dialog przedstawicieli dwóch różnych cywilizacji. Ci dwaj ludzie, wprawdzie reprezentujący wrogie obozy, dostrzegają cechy wspólne mogące przerodzić się w przyjaźń, a potem w pokojową koegzystencję (KT 83). Obydwaj możni widzą, że w miejsce fanatyzmu religijnego chrześcijan i ideologii dżihadu rodzi się umiejętność współistnienia (KT 84-85). Dla Zofii Kossak właśnie tacy ludzie, a nie Renald de Chatillon i jemu podobni, to szansa na przetrwanie chrześcijaństwa i Królestwa Jerozolimskiego w muzułmańskim morzu. Z kolei dla biskupa Beauvais, przybyłego świeżo z Flandrii do Jerozolimy, wspólna dla wyznawców islamu i chrześcijan świątynia w Akce to coś przekraczającego ludzkie pojęcie, powód do grzechu i zgorszenia, dowód na upadek sumienia chrześcijańskiego (KT 69).

Tolerancja religijna widoczna $\mathrm{w}$ miastach pod władzą krzyżowców była faktem potwierdzonym przez źródła. Emir Usama ibn Munkidh wspomina o jednym z kościołów jerozolimskich (będącym dawnym meczetem), gdzie mogli się modlić również muzułmanie ${ }^{19}$. Gdy jeden ze świeżo przybyłych z Europy pątników chciał usunąc siłą Usamę odbywającego modły, przeszkodzili mu w tym dwaj templariusze, którzy przeprosili za zachowanie pątnika ${ }^{20}$. Emir nie omieszkał dodać:

Zdziwiło mnie zachowanie tego szatana, jak się mienił na twarzy, jak drżał na ciele i co się z nim działo na widok modlitwy w stronę qibli ${ }^{21}$.

Dla Zofii Kossak i innych autorów bardzo często chrześcijanie wschodni i „niewierni” mają więcej szlachetności i prawości niż Łacinnicy, przykładem może być cesarz Aleksy I Komnen, król armeński Hettum, wodzowie mongolscy Hulagu i Kitbuka oraz sultan Saladyn.

Łacinnikom imponuje bogactwo i poziom cywilizacyjny Bizancjum, jednak gardzą samymi Bizantyjczykami nie tylko jako ludźmi ich zdaniem miękkimi i zniewieściałymi, ale właśnie jako „podstępnymi schizmatykami” ( $K r$ I 74 i n., II 154). Pojęcie fides Graeca to dla krzyżowców stereotyp postępowania wszystkich Greków ( $K r$ II 282, 300-301). Nawet choroba Gontrany, żony Baldwina lotaryńskiego, nie przekona jej do skorzystania z usług medyka greckiego, bo to przecież „plugawiec, co kraje trupy” ( $K r$ II 252).

Surowość prawa greckiego i sceny wypalania oczu skazańcom ukazane u Kossak rodzi komentarz hrabiego Hugo z Vermandois:

U nas tak ludzi nie męczą. Albo po prostu zachłoszczą, albo żywo spalą, albo teb utną i koniec (...) nie za byle głupstwo jak tu ( $K r$ II 159).

Dowodem waleczności rycerstwa ukazanej Grekom mają być (wspomniane już) worki głów tureckich, które są dla widzów jeszcze jednym dowodem dzikości i barbarzyństwa Łacinników (GF 37; Kr II 264).

19 Zob. Usama ibn Munkidh, op. cit., s. 236; M. Mclville, op. cit., s. 64.

20 Zob. Usama ibn Munkidh, op. cit.

${ }^{21}$ Ibidem. 
Symbolem pobożności u Jarosława Iwaszkiewicza jest książę Henryk Sandomierski, który składa ślub czystości (CT 109, 218). Postać ta w wizji autora jest bardzo bliska ideałowi rycerza zakonnego stworzonego przez Regutę templariuszy oraz Bernarda de Clairvaux w De laude novae militiae $^{22}$. Dla księcia Henryka najważniejszym celem życia jest służba w obronie Krzyża Świętego i przynależność do zakonu rycerskiego (CT 160 i n.). Wątek wstrzemięźliwości i czystości małżeńskiej został wykorzystany przez Zofię Kossak w fikcyjnych postaciach królewicza duńskiego Swenona i córki diuka burgundzkiego Floriny ( $K r$ II 202, 280, 295). Śluby czystości złożone przez oboje młodych, mające trwać aż do chwili dojścia do Jerozolimy, to nie tylko wrogość do grzechu, ale także sprawdzian siły woli i charakteru podczas drogi do Ziemi Świętej (Kr III 25). Dylemat wielu krzyżowców to zawarty w ślubach rycerskich zbyt duży ciężar odpowiedzialności i wierności samemu sobie. Ideał, który jest zbyt doskonały i odległy od zwykłych ludzi, by mu sprostać. Przykładem jest los Stefana z Blois, który odjechał, nie widząc szans ocalenia krucjaty w oblężonej przez wojska emira Kerbogi Antiochii (Kr III 170). Niekiedy upór i chęć wierności swemu postanowieniu doprowadza do tragedii, o czym świadczy los i choroba Swenona, nabyta od jednej z Syryjek (Kr IV 230-231).

\section{Stosunek rycerstwa krzyżowego do kobiet}

Obecność kobiet w krucjatach to osobne zagadnienie. Najpełniej ten wątek jest widoczny u Zofii Kossak. Kobiety Franków pokazane są w I krucjacie początkowo jako postacie ustępujące urodą, ogładą i zwyczajami Bizantyjkom i Syryjkom (Kr II 173). Podobnie też ich mężowie określani są w Aleksjadzie Anny Komneny jako barbarzyńscy „Celtowie”23. Jednak już w Królı trędowatym kobiety Łacinników nie są w niczym gorsze w porównaniu ze wschodnimi rywalkami $(K T 16,32)$.

Postacie kobiet wahają się od wspaniałej i pełnej wdzięku hrabiny Idy de Hainaut, pięknej sułtanki Dżuriszy, mądrej cesarzówny Anny Komneny po prostackie Gontranę i Benignę, złe i podstępne królewny Melisandę i Sybillę. Zofia Kossak postrzega problem udziału kobiet w pierwszej krucjacie bardzo po kobiecemu. To ona w sposób literacki, ustami księcia normandzkiego Roberta Krótkoudego, postawiła pytanie: „czy i kobiety są krzyżowcami?” (Kr III 41-42). Sytuacja opisana przez nią odnosi się wprawdzie do wieku XI, ale szereg innych problemów ukazuje w zawoalowany sposób stopniową emancypację kobiet ( $K r$ III 36). Zaprezentowane przez nią postacie są niekiedy śmieszne i groteskowe lub pełne obaw i słabości kobiecej, jak choćby damy w obozie podczas bitwy pod Doryleum (Kr III 21 i n.).

Kobiety potrafią jednak zdobyć się na heroizm i odwagę. „Anonim pierwszej krucjaty” wspomina o kobietach Łacinników jedynie w sposób pośredni, gdy chwali je za przynoszenie

22 Zob. M. Mclville, op. cit., s. 20-22, 41 i n., 47 in.; J. Trupinda, Krucjatoue poglądy św. Bemarda z Clairvaux a ideologia Zakonu Krzyżackiego zawarta w „Kronice” Piotra z Dusburga, w: Cystersi w'spoteczeństwie Europy Środkowej..., rcd. A. M. Wyrwa, J. Dobosz, Poznań 2000, s. 191-192.

23 Zob. Anna Komnena, op. cit. 
wody walczącym rycerzom i umacnianic ich woli walki (GF 41). Z tej informacji zapewne skorzystała również i Kossak ( $K r$ III 258).

Zestawienie bohaterek Krzyżowców i Króla trędou'atego w pełni ukazuje przemianę obyczajów i zachowań kobiet na przestrzeni około osiemdziesięciu lat. Co było niemożliwe dla babek, stało się normą dla córek i wnuczek ${ }^{2+}$.

Dla niektórych bohaterów literackich stworzonych przez Zofię Kossak postać kobieca to przyczyna grzechu i występku. Tak jak dla demonicznego rycerza Omera de Guillebaut szczerze nienawidzącego płci pięknej, który morduje żonę pod wpływem zrodzonego w jego chorej wyobraźni podejrzenia o niewierność małżeńską ( $K r$ II 199-200, III 24-25). Inna z kobiet, Blanka de Montbeliard otruła w akcie desperacji męża, który ja katował ( $K r$ I 72). Czyn ten wprawdzie znajduje zrozumienie, gdyż rycerz de Montbeliard był znany z podłości i okrucieństwa (Kr I 72). Niedlugo potem jednak nieszczęsna kobieta zostaje oskarżona o czary ( $K r$ II 265 i n.).

Obecność kobiet to stała pokusa do grzechu dla rycerzy, rozumie to biskup Ademar, zdaje sobie jednak sprawę z sily pożądania u ludzi i w głębi duszy nie potępia go ( $K r$ III 130). Wielu krzyżowców w poczuciu potępienia wiecznego nie waha się korzystać z branek tureckich ( $K r$ III 130). Z drugiej strony piękne panie to inspiracja do bohaterstwa i szlachetności rycerskiej, tak zresztą jak w chansons de geste. Przykładem w tej mierze jest u Kossak epizod z bitwy o Nicę:

Z wdzięcznością patrzą na poczciwe białki, czując rosnącą chęć wykazania się w ich oczach. Hej, to już nie zdobywanie „twierdzy miłości”, ani turniej na dziedzińcu, ani gonitwa do pierścienia. Niech widzą dobre dziewczęta, jak walczą ich rycerze, niech się podziwią! (Kr II 259)

Kobiety z ludu bywaly niekiedy jednak obiektem mało wyszukanych zabaw. Usama ibn Munidh po pobycie w Tyberiadzie napisal:

Wystąpili rycerze, by urządzić zabawę z włóczniami. Wraz z nimi wyszły dwie stare, słaniające się kobiety, które oni postawili na końcu placu, na drugim zaś końcu umieścili świnię, którą związali i rzucili na skałę. Kazali tym starym kobietom urządzić wyścigi. Za każdą z tych kobiet jechało kilku jeźdźców, którzy je popędzali. Staruszki upadały i podnosiły się co krok, a oni się śmiali. W końcu jedna drugą wyprzedziła i otrzymała w nagrodę świniaka 25 .

Niekiedy namowy i intrygi kobiece są przyczyną zbrodni, jak fikcyjny wątek postaci Leony, dworki Baldwina lotaryńskiego ( $K r$ III 90 i n.), czy autentyczna postać i złowroga rola królewny Sybilli, która przez swój egoizm i intrygi doprowadziła do zagrożenia bytu Królestwa Jerozolimskiego ${ }^{26}$.

Potrzeby ciała powodują rozdwojenie duszy krzyżowców. Piękne Bizantyjki, Ormianki i Syryjki fascynują urodą, wdziękiem i swobodą obyczajów, z drugiej strony wyzwalają poczucie winy i grzechu

${ }^{24}$ Zob. R. Pernoud, op. cit., s. 47, 121.

25 Usama ibn Munkidh, op. cit., s. 242.

${ }^{26} K T$ 178-179; zob. R. Pernoud, op. cit., s. 111. 
obcowania z kobietami innej wiary i obyczajów (Kr III 126 i n.). Jednakjuż niedługo wielu możnych i rycerzy łacińskich chętnie będzie żeniło się z kobietami Wschodu, jak chociażby wspomniany w Królu trędowatym szlachetny Renald z Sydonu (KT 46).

Drugie i trzecie pokolenie Łacinników w Ziemi Świętej ma świadomość ciagłości tradycji z pierwszymi krzyżowcami (KT 60-61). Są to już jednak ludzie bardziej Wschodu niż Zachodu (KT 57). U Zofii Kossak jeszcze niektórzy starzy rycerze, pokroju Onufrego de Thoron, maja co do tego pewne wątpliwości (KT 60). Nie ma ich już jednak Rajmund z Trypolisu, który dobitnie wskazuje różnicę między pierwszym pokoleniem krzyżowców a ich następcami (KT61-62). Zjawisko to w pełni oddaje kronikarz Fulcher z Chartres, pisząc:

Albowiem my, którzy byliśmy ludźmi Zachodu, teraz jesteśmy ludźmi Wschodu. Kto był Włochem lub Frankiem, na tej ziemi stał się Galilejczykiem lub Palestyńczykiem. Kto był z Reims lub Chartres, teraz Syryjczykiem lub mieszkańcem Antiochii. Już zapomnieliśmy miejsca naszych narodzin; już są dla niektórych z nas nieznane, a przynajmniej mówić już nie chcą. Tu już każdy posiada własny dom i rodzinę; ów już pojął za żonę, nie tylko współrodaczkę, lecz nieraz Syryjkę czy Armenkę, a nawet Saracenkę, która dostąpiła łaski chrztu świętego. Inny ma u siebie zięcia, synową, teścia, pasierba, ojczyma. Nie brak wnuków i prawnuków. Ten posiada winnicę, inny zaś pole uprawne. Kto był obcym przybyszem, teraz stał się tubylcem, a kto był dzierżawcą, stał się stałym mieszkańcem. Albowiem za naszymi przybywają dzień w dzień rodzice i krewni, pozostawiając wszystko, co posiadali. Kto bowiem w Europie był biedny, tego Bóg uczynił tu bogatym. Ci, którzy posiadają mało pieniędzy, tu mają niezliczone mnóstwo bizantów; ci, co nie mieli nawet wsi, już mają miasto, za łaską Bożą 27 .

\section{Prawość rycerska}

Bardzo ważną motywacją dla możnych jest chęć zdobycia własnego, niezależnego władztwa na Wschodzie i ambicje polityczne. Symbolem podobnych postaw jest książę Boemund $z$ Tarentu ( Kr III 172, IV 214 i n.). U Kossak to niemal wzorzec „księcia” Niccolo Machiavellego. Boemund jest waleczny i dzielny, jednak umie też być podstępny i chytry. Ma talent do gry politycznej; jeden z Greków powiedział, że ten książę w odróżnieniu od innych barbarzyńców „nauczył się sztuki nowoczesnego rządzenia państwem” (Kr II 168, 210). Nie zawahałby się w razie potrzeby nawet posunąć do otrucia basileusa Aleksego, gdyby tylko miał okazję (KrII 189). To jego konszachty zjednym z emirów załogi Antiochii bardzo pomogły zająć podstępem miasto (Kr III 160). Z chwilą perspektywy przejęcia przez niego bogatego miasta dotarcie armii krzyżowej do Jerozolimy przestało być dla Boemunda istotne (Kr IV 242).

27 Fulcher z Chartres, Historia Hierosolymitana, w: J. Hauziński, Kraje i kultury śródziemnomorskie, Poznań 1990, s. 265-266; zob. E. Potkowski, op. cit., s. 49-50. 
Bardziej pragmatycznym od swego pobożnego brata Godfryda był także Baldwin lotaryński. Baldwin znał doskonale rzemiosło wojenne, miał jednak w głębokiej pogardzie wiedzę i kulturę (Kr III 91). Nie był w tym odosobniony. Na pytanie jednego z Greków, co ostatnio przeczytał, Hugo de Vermandois odpowiedział, ze

...kiedyś przedukał cały ewangeliarz, ale kiedy nauczył się go prawie na pamięć, czytanie przestało mu być potrzebne ( $K r$ II 154).

Baldwin umie walczyć, jest dobrym administratorem, ale jego wady to podatność na wpływy zauszników i głęboko skrywany kompleks wobec brata. To właśnie dawanie posłuchu intrygantom doprowadziło pośrednio do zabójstwa władcy Edessy, Thorosa, i jego małżonki, dla których Baldwin stał się adoptowanym synem ( $K r$ III 90 i n.). Lotaryńczyk to kolejny symbol krzyżowca. Potrafił zwyciężać Turków, a w przyszłości zostanie tym, który umocni i rozszerzy Królestwo Jerozolimskie $^{28}$. Obca mu była jednak prawość charakteru brata i rycerska szlachetność. Nie jest lojalny nawet wobec swoich, ani tym bardziej wobec „schizmatyków”, którymi gardzi i których obawia się bardziej niż muzułmanów.

U Zofii Kossak małoduszność i podłość Baldwina były przyczyną zagłady oddziału rycerzy normańskich, gdy odmówił im otwarcia bram Tarsu i wpuszczenia do miasta ( $K r$ III 65 i n.). Jego lennik i przyjaciel, rycerz Konon de Montaigu, uosobienie prawości rycerskiej, wstrząśnięty czynem Baldwina decyduje się na odejście do oddziału Godfryda ( $K r$ III 66). Epizod odmowy wpuszczenia do Tarsu Normanów dowodzonych przez Tankreda był opisany przez Gesta Francorum (GF 48), jednak bez tak tragicznych następstw jak u Kossak.

Szlachetność Godfryda de Bouillon czy Prowansalczyka de la Tour z Krzyżowców ukazują doskonale prawość rycerska. Rycerzem uczciwym i prostodusznym u Zofii Kossak był też wspomniany niżej Imbram.

\section{Chęć poznania świata i odmiany losu}

Kolejne motywy udziału większości krzyżowców w krucjatach, zwłaszcza ubogich i chłopów, to przede wszystkim chęć odmiany swego losu, dojście tam, gdzie „nie będzie już panów” (Kr I 95, III 12-13). Dla ubogich rycerzy i giermków bardzo ważne jest zdobycie pasa rycerskiego, sławy i bogactwa, czego symbolem jest rycerz Amalryk de Lusignan w Królı trędowatym. Treść jego listu to niemal kopia cytowanej relacji Fulchera z Chartres o tym, jak ludzie Zachodu stawali się „ludźmi Wschodu” (KT 14-15).

Oprócz pragnienia ratowania Grobu Świętego chęć poznania świata będzie kierowała te $\dot{z}$ jednym z rycerzy śląskich - Imbramem Strzegoniem, bohaterem Krzyżowców. Rycerz Imbram nie będzie zresztą w stanie po powrocie do domu oddać słowem tego, co widział i przeżył. Przekazanie obrazu bogactwa i różnorodności świata, który pozostałym w kraju krewnym wydaje się zbyt nierzeczywistym, by móc w niego uwierzyć, będzie zresztą problemem chyba większości

${ }^{28}$ Zob. S. Runciman, op. cit., t. 2, s. 15 i n.; E. Potkowski, op. cit., s. 43 in. 
krzyżowców, którzy przeżyli ( $K r$ IV 333). Podobne opowieści traktowane są z niedowierzaniem. Dowodem bywają jednak przywiezione przez rycerzy łupy, które w oczywisty sposób są różne od rzeczy znanych ( $K r$ IV 334). Postać Imbrama ma prawdopodobnie swój wzorzec w możnym śląskim Imbramie ze Strzegomia, synu Gniewomira, znanym z nadań dokonanych dla joannitów w $1202 \mathrm{roku}^{29}$.

Na przykładzie opisu zamku i majątku rodu de Lusignan Zofia Kossak ukazała losy i późniejszą karierę typowego zubożałego rodu z Poitou (KT 6 i n.). Postać brata Amalryka, Wita to nawiązanie do autentycznej postaci tragicznego króla Guido de Lusignana, który stał się symbolem klęski rycerstwa jerozolimskiego pod Hittin ${ }^{30}$.

Wit de Lusignan u Kossak to postać krzyżowca odbiegająca od bohaterskiego schematu. Rycerz Wit jest człowiekiem bardzo dobrym z natury, prostodusznym, bez większych ambicji (KT 94). $\mathrm{Na}$ Bliski Wschód, do miejsca, gdzie nigdy nie chciał się udać, posłały go zaślepienie i miłość jego matki oraz ambicje brata. Natomiast intrygi królewny Sybilli i baronów jerozolimskich włożyły na jego barki odpowiedzialność, której nie był w stanie udźwignąc (KT 196).

Chciwość i żądzę zdobycia bogactwa za wszelką cenę dostrzegła u krzyżowców Anna Komnena, której zdaniem

Plemię Latynów, jak już przedtem powiedziano, jest w ogóle bardzo chciwe na bogactwo. Ilekroć postanowi napaść na jakiś kraj, traci rozsądek i nie ma nań żadnego hamulca ${ }^{31}$.

Jednak u Zofii Kossak krzyżowcy wyżej cenią łupy zdobyte w walce aniżeli darowane przez cesarza czy zrabowane ubogiej ludności ( $K r$ II 206). Dla niektórych sposób zdobywania bogactwa nie ma znaczenia. Pan de Melun, chcąc zdobyć środki na wyprawę krzyżową, rabował kupców ze słowami:

Ja idę na świętą wyprawę, wy nie. Podzielcie się ze mną, czym macie, przez miłość Chrystusa Pana (Kr I 102).

Podczas pobytu w Azji Mniejszej rycerz Walter Bez Mienia nie tylko nie walczy z Turkami, lecz łupi i sprzedaje w niewolę chrześcijańską ludność grecką ( $K r$ II 184).

Postacie Baldwina IV i de Lusignana to symbole rozwoju Królestwa Jerozolimskiego. Z jednej strony Baldwin, król mądry i bohaterski, jest śmiertelnie chory. Z drugiej zaś strony Wit de Lusignan, który został królem wbrew swej woli, jest człowiekiem bardzo prawym i szlachetnym, jednak zupełnie bezbronnym wobec takich z gruntu złych ludzi jak wielki mistrz templariuszy i Renald de Chatillon. Właśnie te dwie postacie władców jerozolimskich są personifikacją idei wypraw krzyżowych, idei szlachetnej, lecz często pozostającej pod wpływem ludzi podłych, chciwych władzy i bogactwa, zimnych i głęboko wyrachowanych.

\footnotetext{
${ }^{29}$ Zob. T. W. Lange, Szpitalnicy, joannici, Kawalerowie Maltańscy, Poznań 1994, s. 61-62.

30 Zob. S. Runciman, op. cit., t. 2, s. 414.

${ }^{31}$ Zob. Anna Komnena, op. cit., s. 86 (ks. X, rozdz. 4).
} 


\section{Obraz wojny}

U Zofii Kossak wrogiem krzyżowców są nie tylko Turcy i Arabowie. Znacznie gorszym nieprzyjacielem jest głód, pragnienie, marsz przez pustynię, wzajemne animozje między wodzami, zwątpienie, kryzys wiary. Kolejny przeciwnik to walka z własną słabością i zmysłowością kobiecą, która jest u Kossak jeszcze jednym sprawdzianem siły wiary.

Starcia opisywane przez nią ukazują głęboką dysproporcję sił pomiędzy krzyżowcami a muzułmanami. Autorka wzorem kronikarzy łacińskich przyjmuje setki tysięcy wojowników islamu przeciwko stosunkowo niewielkim siłom Łacinników. Pod Doryleum, według Kossak, armia sułtana Kilidż Arslana miała liczyć aż 300 tys. żołnierzy (Kr III 16). Ponad 100 tys. liczyły też wojska emira Kerbogi pod Antiochią (Kr III 135, 169, IV 181). Autorka nieraz ulegała magii wielkich liczb w Królu trędowatym (KT 130, 211-212).

Zaletą jej powieści są natomiast, bardzo rozbudowane niekiedy literacko, wizje oblężenia Nicei, Jerozolimy i Damietty, bitew pod Doryleum, Antiochią, Hittin. Rycerze krzyżowi walczą pod Niceą i pod Doryleum na podobieństwo bohaterów Pieśni o Rolandzie, którzy mimo ran zabijają wielu Saracenów (Kr II 256-257, III 17-18). W walce rycerstwo dokonuje cudów waleczności:

Na czele swych drużyn Rajmund St. Gilles walczy jak uosobiony żywioł boju, jak Keus. Płomień chodzący. Przy nim Ademar, biskup z Puy. Miecz w jednej dłoni, krzyż w drugiej. Wodze rzucone na łęk. (...) Tuż przy nim Walter Bez Mienia. Ten się nie lęka. Biskup może rzucić wodze, modląc się i bijąc na przemian, bo Walter nad nim czuwa. Nie dbając o siebie, osłania przede wszystkim wodza. Straszliwy jego miecz tnie ludzi wpół, odrzuca z rozmachem precz głowy. Raz po raz czyni się luz wokół biskupa (...) De la Tour przebija kopią szóstego już przeciwnika, wywleka z siodła, unosi do góry, trzyma w powietrzu wbitego w drzewce i ciska $z$ rozmachem bluzgające krwią ciało na szeregi wrogów. Bracia Salviac de Viel walczą ramię przy ramieniu, każdy bardziej baczny na drugiego niż na siebie. Jak żeńcy zboże, tak ścinają wrogów panowie de Foix, de Armaillac, de Luz, de Beaugency. Śląska gromada trzyma się w kupie, rąbie zaciekle niby drwale puszczę. Plunąwszy w garść, walą z rozmachem mieczem od lewego, jak toporem. Padają razy, których nie powstydziłby się sam pan de Melun. (...) Godfryd lotaryński bije się $z$ twarzą uniesioną, natchnioną, nieziemską. Jak gdyby walczył z szatanem twarzą w twarz. Między jednym ciosem a drugim spogląda w górę, spodziewając się ujrzeć tam współwalczącego w obłokach archanioła Michała, wodza wojsk anielskich; świętego Jerzego, pogromcę smoka Lewiatana lub świętego Teodora, Bożego żołnierza. (...) Gdy odrąbuje ramiona, przebija na wylot tułowia, zdaje mu się, że druzgoce Zło samo. Niech się rozpada w drzazgi, niech nigdy nie wstanie! ( $K r$ II 256-257).

Z rezultatu zaciekłych walk po bitwie cieszy się jednak najbardziej kto inny:

$\mathrm{Na}$ pobojowisku siła trupów. Całe zwały to ukazują się, to giną w przebłyskach dnia, gdy na chwilę przerwie się obłok kurzawy. Leżą społem dobrzy rycerze, 
giermcy, pachołki i poganie. Splątani razem w objęciu śmiertelnym, bo walczyli jeszcze na ziemi, do ostatniego tchu. Konie, wielbłądy leżą przewalone. Obok nich wyprute jelita w buchających parą lub strupiałych, zsiniałych już kręgach. Tu i ówdzie odrąbane głowy, ramiona. Bezkształtne tułowia. Nad głowami skulonych ze strachu kobiet łomot skrzydeł. To sępy zleciały na skały. Będą tu czekać do rana. Zdobycz im już nie ucieknie. W swej sępiej mowie wychwalają świętą wojnę. Jakikolwiek jest jej wynik, one osiągają korzyść (Kr II 259-260).

Grozę pola bitwy i zaciekłość zmagań Zofia Kossak i Jan Dobraczyński na kartach swych powieści ukażą jeszcze nieraz.

U Iwaszkiewicza jedynym większym epizodem związanym z walką jest oblężenie Askalonu z 1153 roku (CT 177 i n.). Czerwone tarcze to powieść typowo psychologiczna na tle epoki, a nie tylko mająca ukazać obraz wojen krzyżowych.

Dla Jana Dobraczyńskiego starcie, które zadecydowało o losach świata, to bitwa pod Ajn Dżalut pomiędzy Mongołami a egipskimi Mamelukami (KM 277 i n., 345). Armia mongolska i jej wodzowie pozornie nie są zdolni do wielkich zwycięstw, powieściowy król Hettum przekonał się jednak, że ich wygląd nie przeszkadza im zwyciężać (KM 65). Sposób walki Mongołów początkowo góruje nad taktyką muzułmanów, nie mówiąc już o schematyzmie i zacofaniu wojsk Łacinników. Wyższość mongolskiego sposobu walki zostaje w pełni ukazana podczas zdobycia Aleppo, gdy taktyka pozorowanego odwrotu wciąga oddziały muzułmańskie na lotne piaski (KM 74). Klęska Mongołów pod Ajn Dżalut to efekt zdrady Łacinników, a nie brak woli walki i tchórzostwa, bo przecież do tej pory było tak, jak mawiał Kitbuka: „Zdobędziemy. Chan rozkazał” (KM 240).

W Kluczu mądrości zapowiedzią upadku Królestwa Jerozolimskiego jest postać atabega Az-Zahira Bajbarsa, późniejszego sułtana Mameluków, panującego w latach 1260-1277. W odróżnieniu od szlachetnego i prawego Saladyna, szanowanego nawet przez krzyżowców, Bajbars wierzy wprawdzie głęboko w Allaha, ale przede wszystkim w miecz (KM 161, 248-250). Jego ambicją jest usunięcie z Ziemi Świętej „niewiernych”, tak chrześcijan, jak i Mongołów. Używa argumentu wiary w rozmowach z Łacinnikami i z królem Hettumem (KM 341, 345, 347). Oddziela ją jednak wyraźnie od polityki, mówiąc:

O Koranie i aniołach możesz pomówić z imamami, a nie ze mną (KM 117).

Zdobycie Arsuf przez Mameluków i relacja wielkiego mistrza templariuszy to swoiste memento. Bajbars został określony przez niego „Bestią z Apokalipsy” (KM 350). Ten sam człowiek zdaje też sobie sprawę, w odróżnieniu od Juliana z Sydonu, że sojusz z Mongołami może odsunąć w czasie upadek Królestwa (KM 241). U Zofii Kossak i u Jana Dobraczyńskiego templariusze to jednakże postacie mroczne i przez swe ambicje stanowiące zagrożenie dla państwa, większe niż otwarci wrogowie.

Powieść Dobraczyńskiego to przede wszystkim doskonałe studium charakterów krzyżowców. Niektórzy z nich ukazani są jako ludzie szczerze nienawidzący wszystkiego i wszystkich, co nie mieści się we wpojonych im schematach myślowych, a podłość i nielojalność oraz głębokie 
podziały i ambicje wśród baronów są gorsze od wojny i zagrożenia ze strony muzułmanów (KM 238, 339-340).

U Mongołów, zwanych potocznie „Tartarami”, Łacinnicy występujący w powieści widzą tylko ich brzydotę fizyczną, brud i okrucieństwo, poparte wieściami z Rusi, Polski i Węgier (KM 242). Nawet życzliwego „Tartarom” króla Hettuma razi w powieści rzeź Aleppo dokonana przez azjatyckich zdobywców, nie waha się nawet zabić kilku wojowników w obronie mordowanych (KM 80 i n.).

Opinie krzyżowców cytowane w Kluczu mądrości są niemal żywcem przejęte z ocen widocznych w niektórych źródłach ${ }^{32}$. Ocena zaprezentowana w Opisaniu świata przez Marco Polo, prezentująca w pozytywnym świetle Mongołów, nie byłaby zrozumiana przez krzyżowców. Dla nich „Tartarzy” to wysłannicy Piekła. Muzułmanie bywają wrogami, ale przecież nie zawsze. Potomkowie krzyżowców, mimo niechęci i częstych wojen, potrafili przyjąć podobny styl życia, co muzułmanie, i pewną wspólnotę kanonów cywilizacyjnych, mimo istniejących różnic kulturowych. Julian z Sydonu używa argumentu zastosowanego przez sułtana egipskiego wobec wspólnej z krzyżowcami obrony wiedzy, sztuki i religii przed Mongołami — „chyba, że ktoś woli śmierdzący kożuch od jedwabiu i wina" (KM 240).

Odmienność kulturowa i cywilizacyjna Mongołów jest nie do przyjęcia, i nawet fakt, że chcą walczyć o Krzyż i Jerozolimę, nie przysporzy im sympatii Łacinników (KM 241). Miarą wrogości krzyżowców do „sojuszników” staje się fakt zakulisowych kontaktów z Egipcjanami (KM 117, 238). U Dobraczyńskiego jednak to nie Łacinnicy, lecz Ormianie i Mongołowie są bardziej chrześcijańscy od tych, którzy nazywają siebie chrześcijanami.

Przedstawione przez Zofię Kossak i Jana Dobraczyńskiego opisy wypraw krzyżowych są doskonałym studium problemu na kanwie powieści historycznej wspartej znajomością źródeł. Literackość opisu i fikcyjność niektórych postaci i sytuacji nie odbiega w rażący sposób od wydarzeń autentycznych i opisu krucjat zawartego w źródłach, między innymi u Anonima i Anny Komneny, Wilhelma z Tyru czy Fulchera z Chartres. Wiarygodności wszystkim powieściom przydają postacie autentycznych krzyżowców i ich przeciwników, nieco tylko literacko wzbogacone. Znajduje to także potwierdzenie w opracowaniach i syntezach późniejszych, w tym Stevena Runcimana, Petera Malcolma Holta i Régine Pernoud. Postać księcia Henryka Sandomierskiego u Iwaszkiewicza została bardzo wzbogacona psychologicznie i uwiarygodniona. Jednak większość kontaktów księcia (między innymi z Fryderykiem Barbarossą czy młodym Saladynem) stanowi fikcję literacką i nie ma dostatecznego potwierdzenia w źródłach. W świetle źródeł, dokumentów dla joannitów z Zagości czy późniejszego Jana Długosza, wiadomo o nim stosunkowo mało ${ }^{33}$. Był jedynym z synów Bolesława Krzywoustego, który nie angażował się w walki o Kraków, lecz w krucjaty, zarówno na Bliskim Wschodzie, jak i przeciw poganom nad Bałtykiem ${ }^{34}$. Jego śmierć na wyprawie przeciw Prusom w 1166 roku była dowodem, że idea wojny krzyżowej nie była na ziemiach polskich obca.

${ }^{32}$ Zob. J. di Piano Carpini, Historia Mongotów, tł. S. Młodecki, opr. T. Jasiński, K. Pietkiewicz, J. Strzelczyk, Z. Wojtkowiak, w: Spotkanie dwóch światów. Stolica Apostolska a świat mongolski w potowie XIII wieku. Relacje powstate w zwiazku z misja Jana di Piano Carpiniego do Mongolów, red. J. Strzelczyk, Poznań 1993, s. 128.

33 Zob.J. Długosz, Roczniki albo kroniki stawnego Królestwa Polskiego, red. J Dąbrowski [i in.], ks. V-VI, Warszawa 1975, s. 64-65; K. Tymieniecki, Majętność książęca w Zagości i pierwotne uposażenie klasztoru joannitów na tle osadnictwa dorzecza dolnej Nidy. Studium z dziejów gospodarczych XII w., w: idem, Pisma uybrane, Warszawa 1956, s. 35 in.

34 Zob. R. Grodecki, S. Zachorowski, Dzieje Polski średniowiecznej, t. 1, Kraków 1995, s. 176; M. Tymowski, Henryk Sandomierski, w: Poczet królów i książq̨ polskich, red. A. Garlicki, Warszawa 1978, s. 105. 